\title{
Critical Analysis of State of Women's Rights in Nigeria
}

\author{
E.Q. Okolie Esq LLB, (Hons.) BL, LLM, Ph.D FIPMD \\ Senior Lecturer and Former Head of Department, Faculty of Law, Chukwuemeka Odumegwu Ojukwu \\ University, Igbariam Campus Anambra State. \\ E-mail: enrightque@gmail.com; Tel.: +2348033762068
}

\begin{abstract}
Notwithstanding the provisions of the 1999 Constitution and several International and Regional treaties such as the International Covenant on Civil and Political Rights (ICCPR), the Convention On the Elimination of All Forms of Discrimination Against Women (CEDAW) and the Protocol to the Africa Charter on Human and People's Rights on the Rights of Women in Africa; discrimination and violations of women's rights still occupying in Nigeria. Women are discriminated against in the area of politics, decision-making and other spheres; Nigeria is still one of the countries with the highest maternal mortality rate in the world; violence against women exist both in the private and public lives and there are still discriminatory laws that violate the rights of women in our law books. This paper examines the current realities of women's rights in Nigeria under seven headings i.e. Gender Based Violence, Women's Access to land, Access to Justice and Equal Protection Under the Law, Health and Reproductive Rights, Right to Participation in Political and Decision-Making Processes, Right to Inheritance and Marriage, Separation, Divorce and Women's Property Rights. Also, the positive actions that have been taken to address these issues such as the passage of the Violence Against Persons Prohibition Act and the development of the Standards and Guidelines for the medical management of victims of violence in Nigeria will be discussed. Finally, actions that are required towards the realization of women's rights will also be appraised.
\end{abstract}

Keywords: women's rights, Nigeria, discrimination

DOI: $10.7176 / \mathrm{JAAS} / 53-07$

\section{Introduction}

Today, the issue of Women's Rights has become a buzz word, the world over. It is a great concern to many women that are deprived of their human rights. It has been a burning issue in different parts of the world, yet some think it is all a propaganda, blown out of proportion usually because of religious or cultural inclinations.

A right is defined as a power, privilege or immunity guaranteed under a constitution, statute or case law or claimed as a result of long usage. In moral vocabulary, respect for rights is seen as a matter of justice. Rights can be asserted, demanded or stood upon. The obligations they impose are expected to be performed and their nonperformance occasions feelings of indignation, resentment and disappointment. ${ }^{1}$ Article 1 of the Universal Declaration of Human Rights states that "all human beings are born free and equal in dignity and rights."”

According to the Global Funds for Women, Women's rights are the fundamental human rights that were enshrined by the United Nations for every human being on the planet nearly 70 years ago. These rights include the right to live free from violence, slavery, and discrimination; to be educated; to own property; to vote; and to earn a fair and equal wage. ${ }^{3}$ The human rights of women are an inalienable, integral and indivisible part of universal human rights and human rights are basic freedoms that are due to human beings because of their being humans.

The Constitution of the Federal Republic of Nigeria guarantees right to freedom from discrimination. ${ }^{4}$ No one shall be discriminated upon by reason of his or her sex, religion, ethnicity, political opinion or the circumstances of his or her birth. It is therefore congruent to state that this constitutional provision considers it an aberration to discriminate against women.

Also, Nigeria is a signatory to several global and regional legal instruments which seek to protect the rights of women. Some of these legal instruments include the Convention on Elimination of All Forms of Discrimination against Women (CEDAW), Protocol to the African Charter on Human and People's Rights on the Rights of

\footnotetext{
${ }^{1}$ The lawyers Chronicles http://www.thelawyerschronicle.com/the-rights-of-women-in-nigeria/

${ }^{2}$ Universal Declaration of Human Rights 1948

${ }^{3}$ Global fund for women https://www.globalfundforwomen.org/womens-human-rights/\#.Wx-tnNUzbIU

${ }^{4}$ Section 42, 1999 Constitution of the Federal Republic of Nigeria (as amended)
} 
Women in Africa which is popularly referred to as The 'Maputo Protocol'. Article 5 of the Convention on the Elimination of all forms of Discrimination Against Women (CEDAW), adopted by the United Nations General Assembly in 1979, signed and ratified by Nigeria in 1984 without any reservation, "encourages nations to modify the social and cultural patterns of conduct of men and women with the view to eliminate inferiority and superiority of either sexes or stereotype roles of men and women."

The Solemn Declaration on Gender Equality in Africa to which Nigeria is a signatory, reaffirms the principle of gender equality as enshrined in Article 4(1) of the Constitutive Act of the African Union. In chapter 7, member states declare "to actively promote the implementation of legislation to guarantee women's land, property and inheritance rights including the right to housing".

The African Charter in Human and Peoples Rights (ACHPR) was domesticated in Nigeria in form of the African Charter on Human and Peoples Rights (Enforcement and Domestication) Act Cap 10, 1990. This Act makes the provisions of the Charter enforceable in any Court of Law in Nigeria. Article 18 (3) of the ACHPR states that "the State shall ensure the elimination of every discrimination against women and also ensure the protection of the rights of women...."

Article 21 of The Optional Protocol to the African Charter on Human and People's Rights on the Rights of Women in Africa 2003 (ratified by Nigeria in 2004) states that "a widow shall have the right to an equitable share in the inheritance of the property of her husband. A widow shall have the right to continue to live in the matrimonial house. Sub paragraph (2) of the above states that "women and girls shall have same rights as men and boys to inherit in equal shares their parents' properties.

I had taken the liberty to refer to a few of the regional instruments above which are generally considered 'home grown' because they were developed and put together by Africans for Africans as against some of the global legal instruments which some critics have labelled as 'western' in nature, choosing to forget that human rights are universal, in respective of where you come from.

\section{The Nigerian Reality}

From the foregoing, the rights of women can be said to be well enshrined in the law books. The big question worth asking is: whether the provisions of these laws and legal instruments translated to an improvement in the lives of Nigerian women as compared to their male counterparts or not? How has these improved the wellbeing of Nigerian women? We will briefly look at seven thematic areas to ascertain how women's rights have fared in Nigeria.

\section{Gender based violence}

The incidence of Gender Based Violence (GBV) in Nigeria is growing astronomically in progression. From Forced and Early marriages to physical, mental and sexual assault on a woman, nearly 3 in 10 women have experienced physical violence by age $15 .{ }^{1}$ Although, the Constitution and several global and regional legal instruments guarantee women's freedom from violence, the reality today is that, there is still a high prevalent rate of violence against women, ranging from domestic violence, sexual violence and exploitation, female genital mutilation, forced and early marriages, widow torture and inheritance related violence.

One in three of all women and girls aged 15-24 has been a victim of violence. Women who have never married are more likely to have been attacked or more vulnerable to attack than married women. ${ }^{2} \mathrm{~A}$ situational analysis conducted across Africa reported that 18.3 percent of women in Nigeria have experienced intimate partner physical/sexual violence in their life time. The 2018 National Demographic Health Survey reported that 28 percent of women of reproductive age in Nigeria reported physical violence, while 7 percent reported having experienced sexual violence at least once in their life time. ${ }^{3}$

The case is worse in humanitarian settings as we currently have seen in the North East of Nigeria. According to a recent report released by Amnesty International, since early 2017, the Nigerian military has carried out extensive operations and recaptured vast swathes of territory that had come under the control of Boko Haram in the northeast of the country. However, instead of "freeing" hundreds of thousands of people who had been trapped in these areas, the military has carried out systematic patterns of violence and abuse against this population,

\footnotetext{
${ }^{1}$ Nigeria Demographic Health Survey, 2018

${ }^{2}$ Gender in Nigeria Report, 2017

${ }^{3}$ Standards and Guidelines for the Medical Management of Victims of Violence in Nigeria 2017
} 
including war crimes and possible crimes against humanity. Women have been affected in disproportionate and gender-specific ways, and continue to face ongoing discrimination and violence. Nine women and girls told Amnesty International of cases they knew of in which women had been raped by soldiers or Civilian Joint Task Force members in the satellite camps. These women said they were raped after they refused to have sex in exchange for food or other assistance, or after they were intercepted on their way to collect water outside the camp. ${ }^{1}$ Women have generally been used as sex slaves in the theatres of war. The case of the Chibok girls is still very fresh in our memories.

\section{Right to Inheritance}

In most parts of Nigeria today, female children are still being discriminated against on issues of inheritance, and succession especially under native law and custom. Although, the law forbids discrimination against women in all its form, in reality, this is not the situation for women especially those married under customary law. The court has constantly held that these practices were repugnant to natural justice, equity and good conscience as seen in the case of Motoh v. Motoh ${ }^{2}$. Here, the court held that the native law and custom of umuanaga Awka which discriminates against female children of the same parent and fathers and the male children who inherit all the estate of their father to the exclusion of their female siblings is repugnant to natural justice, equity and good conscience. This is in line with the provisions of Section 42 of the 1999 Constitution of Federal Republic of Nigeria (as altered).

Only recently in 2016, the Supreme Court in a landmark judgment, nullified the Igbo law and custom which prevented women from inheriting their father's estate. The apex court ruled that the practice was discriminatory and conflicts with the provisions of the Nigerian Constitution. The court specifically held that the practice was a breach of Section 42 (1)(a) and (2) of the 1999 Constitution (as altered). The apex court's judgment was based on the appeal filed in 2004 by Mrs Lois Chituru Ukeje (widow of the late Lazarus Ogbonna Ukeje) and their son, Enyinnaya Lazarus Ukeje against Mrs Gladys Ada Ukeje (the deceased's daughter). Gladys had sued the widow and son before the Lagos High Court, claiming to be one of the Ukeje's children and sought to be included among those to administer their father's estate. The trial court affirmed that she was Ukeje's daughter and was therefore qualified to benefit from the estate of her father who died in Lagos in 1981. At the Court of Appeal, sitting in Lagos, which Mrs Ukeje and his son rushed to, the decision of the trial court was upheld, prompting them to approach the Supreme Court. In its judgment on July 1, 2016, the Supreme Court held that the Court of Appeal, Lagos was right in voiding the Igbo's native law and custom that disinherits female children. Justice Bode Rhodes-Vivour, who read the lead judgment held that no matter the circumstances of the birth of a female child, she is entitled to an inheritance from her late father's estate. "Consequently, the Igbo customary law, which disentitles a female child from partaking in the sharing of her deceased father's estate, is a breach of Section 42(1) and (2) of the Constitution, a fundamental rights provision guaranteed to every Nigerian whether male of female.

"The said discriminatory customary law is void as it conflicts with Section 42(1) and (2) of the Constitution. Justice Rhodes-Vivour ruled. Justices Walter Samuel Nkanu Onnoghen, Clara Bata Ogunbiyi, Kumai Bayang Aka'ahs and John Inyang Okoro, who were part of the panel that heard the appeal, agreed with the lead judgment. $^{3}$

Despite these bold pronouncements by the courts, many women still experience discrimination in terms of their right to inheritance. Only those who are bold enough and have the wherewithal to go to court can enforce their right to inheritance, and they are very few. The reality is that laws and the brilliant pronouncements by the courts have not proven sufficient to eliminate discrimination against women as is currently experienced, in Nigeria.

\section{Access to Justice and Equal Protection under the Law}

Article 8(f) of the Optional Protocol to the African Charter on Human Rights on the Rights of Women enjoins all State parties to reform existing discriminatory laws and practices in order to promote and protect the rights of women.

Notwithstanding the above provision, the Constitution and certain laws in Nigeria still contain discriminatory provisions against women, which need to be amended. For instance, Section 26(2) of the Constitution does not

\footnotetext{
1 "They Betrayed Us". Women who survived Boko Haram raped, starved and detained in Nigeria, Amnesty International

2 (2011) 16 NWLR PT 1274474 CA

${ }^{3} \mathrm{http}: / /$ radionigeriaenugu.com/supreme-court-female-child-can-inherit-property-in-igboland/
} 
allow a Nigerian woman to transmit her nationality to her foreign husband whereas the Nigerian man is able to transmit his nationality to his foreign wife.

Also, by the provisions of Section 55(2) of the Penal Code applicable in Northern Nigeria, the law permits wife battery as chastisement provided grievous bodily harm is not inflicted. Section 55 of the Labour Act also prohibits women from working in the night. There are several other laws like deny equal access and treatment for women in comparison with their male counterparts. Some have argued that some of these provisions in these laws were intended to protect women and to secure their well-being. For many decades, women were not considered eligible to be enlisted as combatants in the armed forces. With constant and steady advocacy, today women are now enlisted as combatants in the armed forces.

\section{Health and Reproductive Rights}

With a maternal mortality ratio of 576 deaths per 100,000 live births, Nigeria continues to have one of the highest levels of maternal mortality. ${ }^{1}$ One Nigerian woman dies in childbirth every ten minutes. Spending and implementation have not matched policies. Nigeria spends only $6.5 \%$ of its budget on health care. ${ }^{2}$ Incidences of gender-based violence have health consequences and result in health complications including miscarriages, long term disabilities, unwanted pregnancies, HIV/AIDS and other sexually transmitted diseases. Women in Nigeria are still denied their reproductive health rights to choose the number of children they want to have or to choose whether to carry a pregnancy to term in the event of rape or incest.

The maternal health indicators, as well as reproductive health indices for Nigeria are one of the worst in the world. Nigeria's Total Fertility Rate is 5.67; Contraceptive Prevalence Rate is 15\%: Life time risk of maternal death is $1 / 29$. What this means is that Nigeria is one of the worst places for a woman to have a child. This explains why women are dying daily. Permit me to quote one of the popular quotes of the legendary Egyptian Professor of Obstetrics and Gynaecology, Prof Mahmoud Fathalla who chaired the 1994 International Conference on Population and Development that held in Cairo. He said "women are not dying because of diseases they cannot be teet. They are dying because scien have yet to make the decision that their lives are worth savins." 3

\section{Right to Participation in Political and Decision Making Processes}

Women constitute about half of the population in Nigeria, yet they face endemic discrimination and persistent denial of their rights. ${ }^{4}$ From the period leading to Nigeria's independence to date, even though some advances have been made in women's participation in governance, yet the political participation of women in Nigeria remains one of the lowest in the world. Despite their huge population, women are the least represented in leadership and governance positions in the country and that has been the sorry state of affairs till date.

Women's participation in government is still a far cry from the expected 35 per cent as stipulated in the National Gender Policy. In the recent election conducted in 2015, out of the 360 members of the House of Representative, only 15 are women. In the Senate, out of the 109 members only seven are women. Women representation at the National Assembly is below 10 per cent. At the executive arm of government, women participation is less than 3 per cent.

The equal participation of women and men in political, civil, economic, social and cultural life, at the national, regional and international levels, and the eradication of all forms of discrimination on the grounds of sex are priority objectives of the international community. ${ }^{5}$ Nigeria therefore needs to work extra hard to bring this to reality.

\section{Marriage, Separation, Divorce and Women's Property Rights}

Although Article 7 of the Protocol to the Charter on Human and Peoples Rights on the Rights of Women in Africa provides for both parties to a marriage to enjoy equal rights within and after the marriage, in issues of custody and access to an equitable share of the joint property deriving from the marriage, this is not the case. Three forms of marriages are recognized in Nigeria - Customary, Islamic and Marriage under the Act. The

\footnotetext{
${ }^{1} 2018$ National Demographic Health Survey

${ }^{2}$ National Gender Report 2012

3 https://www.figo.org/sites/defau!t/files/uploads/PublicationsandResourcesFathallafiles/c/29\%20Safe $\% 20 \mathrm{mother}$ hood $\% 20$ at $\% 20$ twenty $\% 20$ five $\% 20-\% 20$ Looking\%20back\%20moving\%20forward.pdf

${ }^{4}$ Multi-sectorai Approach to Women's Rights in Africa - Manual by Florence Butegwa and Taaka Awori, Sept. 2010, UN Women.

${ }^{5}$ Vienna Declaration and Programme of Action, 1993, paragraph 18
} 
reality of women married under Customary and Islamic law has not yet been affected by the protocol. A woman married under customary law is entitled to be provided with a home by her husband as long as the marriage subsists. She is also entitled to use her husband's property but cannot dispose of it as her own. The right to be provided with a house by her husband terminates upon divorce. Upon divorce, a woman married under customary law has no claim over a house jointly owned by her husband. Her position is not helped by the provisions of the Matrimonial Causes Act in respect of maintenance and settlement of property, which expressly excludes the application of its provisions to marriages under customary and Islamic law. However, in the case of women married under the Act, where she is able to produce documents or by oral evidence showing she made a contribution to the property, she is entitled to the part of the property commensurate to her contribution. Many women married under native law and custom have been sent parking after so many years of marriage with nothing to show for it.

\section{Women Access to Land}

An estimated 54 million of Nigerian population are women and they are based in rural areas and make a living from the land. ${ }^{1}$ The Nigeria Land Use Act of 1978 nationalized all land and vested authority in the State Governor who holds it in trust on behalf of all. In practice however, the way land is owned and accessed varies from place to place in Nigeria and can be an amalgam of traditional Islamic Sharia and other local governance practices. In rural areas, women's rights of access are still regarded as secondary to those of men and many customs suggest that women's access to land is still mediated via patrilineal systems, in spite of the intentions of the 1978 Land Use Act. For women, user rights often follow marriage, inheritance or borrowing. Traditionally, only Muslim women own land outright where inheritance practices mean they are entitled to a-third of inheritance. The livelihood challenge is as much about access to land as it is about obtaining the means to use the land. In rural Nigeria land ownership is one of the key limiting factors of production. Land access is severely curtailed by the way land is inherited, owned and passed on by men to their male descendants in most patrilineal ethnic groups, especially in Southern Nigeria. For Muslim women, it can be curtailed by traditional male decision making power over female access to assets. ${ }^{2}$

\section{Findings $^{3}$}

\section{a. Transfer of right:}

the nature of the practice is an indication and confirmation that a woman is viewed as chattels with a price tag that is purchased by a person who pays the price. The "purchaser" like a purchaser of goods in law has a right to deal with the "purchased chattel" in any manner. This is the attitude of men under customary law as regard their wives.

\section{b. Loss of right:}

After the payment of the bride, the woman remains married to the man who paid it. If the marriage breaks down the woman must return the bride price to the man for her to regain her freedom. Non-repayment of the bride price allows the estranged husband to retain the right to any children the woman produces. The issue is more severe where the father of the married woman is unable to refund the bride price for economic reasons.

\section{Children in Marriage under Customary Law}

Children play an important role in any marriage under customary law in Nigeria. They occupy the central point in the marriage. Fertility in marriage is considered of paramount importance, unlike in the Western world. The love for children is exhibited in some of the names given to children in Nigeria. Names like amuta nwa, nwa amuta ibe ya ("it is good to have a child who also beget his own child for the continuity of the generation") emphasize the importance attached to children under the Igbo culture.

In the Igbo culture, names such as Nwabu-Uwa, literally meaning a child is priceless or most precious, and Nwaka-aku, a child out values money, are an indication of the value placed on children. A childless woman under customary law in Nigerian culture is regarded as a source of disappointment to her family and husband. In Yoruba culture, she is referred to as an "empty gourd" signifying waste, emptiness, or usualness. In the Igbo culture the position is the same. A childless married woman is called Nwanyi-Iga (sterile woman) or "a man."

\footnotetext{
${ }^{1}$ Gender in Nigeria Report, 2012

${ }^{2}$ Gender in Nigeria Report 2012

${ }^{3} \mathrm{https}$ ://books.google.com.ng
} 
The myth is that she is a witch who has killed in a mysterious way all the children she should have given birth to in the world.

\section{Effect}

Childlessness in a marriage is blamed on the woman and never the man. She is blamed, abused, and ridiculed, while the man is pitied, pacified, and advised about alternative ways of having children. This has caused problems in marriages and at times resulted in divorce and polygamy with the attendant problems.

\section{Family without a male child}

Gender discrimination is common practice in Nigeria. The preference for male children to the detriment of the girl children is still common in Nigeria. Male sons are seen as necessary to ensure continuity of the generations to come of the family. All of these marital protocols have various implications in our African cultures. However, a lot of changes are now underway to promote women's rights to inheritance of their husbands' properties if death occurs. We believe very strongly that women will achieve their rights in a very near future.

\section{Positive actions taken by the government to protect women's rights in Nigeria}

- $\quad$ Adoption of the National gender policy in 2007,

- $\quad$ Passage of the Violence Against Persons Prohibition Act in 2015

- Development of a standards and guidelines for the medical management of victims of women's rights violations. But we understood recently that that the said bill has been ressed into law.

- $\quad$ Establishment of Women Development Centres in Nigeria in 36 states;

- Adoption of the Trafficking in Person's (Prohibition) Law Enforcement and Administration Act;

- $\quad$ Establishment of a National Agency for the Prohibition of Trafficking in Persons;

- Adoption of a national policy on HIV/AIDS, reproductive health and female genital mutilation.

\section{Areas still requiring actions from government}

- Adoption of the Violence Against Persons Prohibition Act by States that are yet to pass it

- Domestication of the Optional Protocol to the Africa Charter on Human Rights on the Rights of Women through the passage of the Gender and Equal Opportunity Bill, presently at the National Assembly.

- Reformation of existing discriminatory laws in the Constitution and other statute books

- Political Will to address gender equality.

- $\quad$ Economic empowerment of women.

\section{Conclusion}

From the foregoing the current state of the Rights of Women in Nigeria is in dire straits. There is clearly no political will on the part of government at all levels to address the issues of women rights. In my opinion, Nigeria is not in short supply of laws that guarantee the rights of women. How many of them know about these laws and have the capacity to ensure that these rights are enforced? This is one of the great challenges facing the Nigerian woman. 